\title{
John Morton Coles (1930-2020). From Palaeolithic Studies to Wetland Archaeology. A Commemoration
}

\author{
Danuta Piotrowska $^{a}$ and Wojciech Piotrowski ${ }^{b}$
}

\begin{abstract}
This article is dedicated to John Morton Coles (1930-2020), Professor of European Prehistory at Cambridge University between 1980 and 1986, Fellow of the British Academy, author of the highly regarded scientific works, teacher and editor. He dealt with several archaeological periods and was involved in different field projects and conducted numerous excavations.

At Cambridge, in the Department of Archaeology, John Coles collaborated with such significant figures as Professors Grahame Clark and Glyn Daniel. John Coles devoted much of his time to experimental and wetland archaeology as well as to prehistoric rock carvings in Sweden and Norway. John Coles was awarded an honorary doctorate by Uppsala University. He was the advisor of Biskupin's archaeological open-air Museum in Poland.
\end{abstract}

KEY-WORDS: John Morton Coles (1930-2020), British archaeology, European Prehistory, Cambridge University, Somerset Levels Project, Scandinavian rock carvings, open-air museum at Biskupin

Many archaeologists limit their scope of research to one archaeological period or subject. Others limit themselves to conducting excavations and publishing the results. This was not the case with John Coles. Much like V. Gordon Childe, he dealt with several periods, while his activity in the field of archaeology was even more diverse. It played out across the Palaeolithic, Mesolithic, Neolithic, Bronze and Iron Ages, traditionally understood as nearly the whole of prehistory, as well as in the experimental, wetland and environmental sub-fields of archaeology. He was both teacher and researcher, and gave university lectures and conducted numerous excavations. He was President of the

a State Archaeological Museum in Warsaw, Długa Street 52, o0-24I Warszawa; e-mail: d.piotrowska@ pma.pl; https://orcid.org/o0oo-o0oI-5704-I223

$b$ Polish Academy of Sciences, Archives in Warsaw, Nowy Świat Street 72, 00-330 Warszawa; e-mail: wojbiskupin@wp.pl; https://orcid.org/oooo-oooI-9659-6934 
IS6 $\mid$ Danuta Piotrowska and Wojciech Piotrowski

Prehistoric Society and a member of the editing boards of archaeological periodicals, including Proceedings of the Prehistoric Society and Antiquity, an outstanding organizer and a populariser of science. In 1978, he was elected Fellow of the British Academy.

John Coles was born on 25 March 1930. Like Childe, he arrived in Britain from one of its dominions, in John's case from Canada. His grandfather had emigrated from England to Canada and settled in Woodstock, Ontario, a small town not far from the border between Canada and the United States. His father had grown up there, and both his parents were involved with the activities of the town, while summer holidays were spent on the shores of Lake Huron. After leaving school in Woodstock, John went to Victoria College, University of Toronto, and graduated in Classics in 1952. During his studies he also played tennis, and he was awarded his tennis colours in the same year. Following his graduation, he worked from 1952 to 1955 at his father's office in Woodstock. His father's real-estate, insurance and investment business was not what John dreamt of: in the introduction to his memoir, Yesterday's Man, he described the work as "doing things that were of little interest of me, buying and selling" (Coles 2019: I).

The summer of 1955, young Coles spent travelling around Europe as a tourist. This was his first encounter with the rich prehistory of the western part of the continent. In August 1955, he reached England. With the support of his parents, he decided to

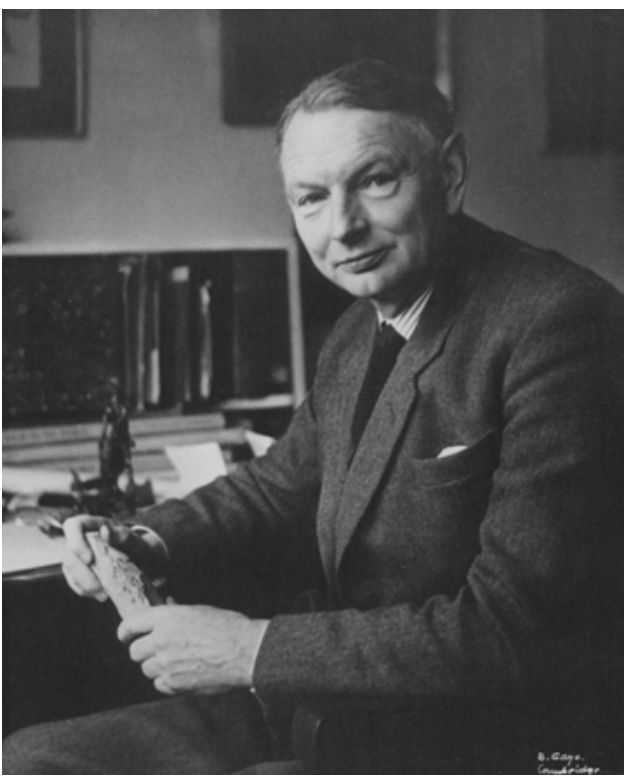

Fig. 1. Grahame Clark (1907-1995). Photograph after Proceedings of the Prehistoric Society, vol. XXXVII, part II ('Contributions to Prehistory Offered to Grahame Clark') 1971. take up studies in ancient history and archaeology. Friends in Lincolnshire introduced him to Cambridge University and his adventures with archaeology began, owing in part to the kindnesses of persons such as Dr Leslie Wayper and Mary Thatcher. Probably it was because of them that Professor Grahame Clark (1907-1995) honoured John with an invitation to tea, and there and then accepted him as a new student, something John was to recall with appreciation in his memoir (Coles 2019: 2). Professor Clark (Fig. I) later wrote, in Prehistory at Cambridge and Beyond, that "Coles himself had come to Cambridge as an affiliated student from Toronto" (Clark 1989: 63).

John's time as a Cambridge student, from 1955 to 1957 , is vividly depicted in his last publication, the memoir Yesterday's Man. An archaeological life 1955-1980 
(Coles 2019). It includes many insightful characterisations of significant figures he met during his time at university and throughout his scientific career. To readers from mainland Europe, it is an interesting source of information about archaeological education at Cambridge in the 1950s and 6os. ${ }^{1}$

John recalled many amusing situations from within the walls of the University as well as from extensive field work. Here is one example:

\footnotetext{
"The projection of slides, hand-operated by a member of the faculty Assistant staff, was something amusing with upside-down pictures and we students would count the number of times a confusing slide could be projected before it appeared correctly; we never I think got to the number seven, but the junior lecturers could get flustered easily and we doubtless had little sympathy with them unless some catastrophic event occurred such as the projector bursting into flames, a glass slide shattering in situ, or the screen collapsing; all of these happened during my time there" (Coles 2019: 6).
}

Although his final book is a mere II4 pages long, it is a memoir of a researcher with a sense of professional fulfilment, in which he describes himself, his contemporaries and events with subtle and humorous detachment.

A salient feature of course structure at Cambridge at that time was a division into two Parts. Part I was a year-long introduction to Archaeology, Physical Anthropology and Social Anthropology. Part II was a two-year course in just one of the above disciplines and with some specialization within the single subject, leading to a Diploma. For this John chose Palaeolithic Archaeology, and Geological and Botanical courses. Additionally, for students of Part II, the curriculum included two general thematic series, one on the Aims, History and Scope of the subject, and one on Methods and Techniques. At this time, the Department of Archaeology employed as lecturers and directors of courses such significant figures as Professor Grahame Clark (Head of the Department), Dr Glyn Daniel (1914-1986) and Dr Charles McBurney (I9I4-1979). When John Coles arrived, earlier alumni of the Department such as Louis Leakey (1903-1972), Thurstan Shaw (1914-2013) and Desmond Clark (1916-2002), were making the prehistory from Cambridge famous far beyond the borders of Great Britain (Clark I989: 29 and 52; Smith 2009: II7-I22 and I82-I89).

Dr Miles Burkitt (I890-197I) and Dr Charles McBurney played an important part in John's Palaeolithic studies. His relationship with these scholars, both professional and personal, as well as his connection to Grahame Clark, had a formative influence on John Coles as a researcher, academic teacher and archaeologist leading numerous multidisciplinary projects. On top of all that, he played tennis, which also shapes the character (Coles 1997; 2019: 18, 28; Coles J. et al., 1999).

1 Preceding decades are depicted in a well researched book by Pamela Jane Smith (2009). 
I58 $\mid$ Danuta Piotrowska and Wojciech Piotrowski

In the memoir written for the British Academy following the death of his first teacher at Cambridge, and published in its Proceedings, John admitted:

"As a University Lecturer, Clark was not always appreciated by his students. His lectures were generally considered to be rather poorly constructed, and often wandered from the subject in hand" (Coles 1997: 370).

But it was Clark who, through his exemplary research at Star Carr (North Yorkshire) introduced John to the field of Mesolithic archaeology and wetland archaeology. Following Clark's publication of the site in 1954, it soon became a milestone for the development of wetland archaeology internationally (Clark 1954; 1972, see also Renfrew and Bahn I991: 33; Fagan 200I: I45-I68; Trigger 2007: 358-360). Clark's previous book Prehistoric Europe: the Economic Basis (1952) inspired a new generation of young researchers such as Coles himself to broaden their scientific horizons. It was translated into Polish and carefully released in Warsaw five years after the English edition. The translator was Józef Kostrzewski (1885-1969), an eminent Professor of the University of Poznań. According to Jacek Lech, Kostrzewski's intention was to demonstrate how it was possible "to research the economic basis outside Marxist methodology", because:

"...Clark was doing it much better than Marxist prehistorians were, or historians of material culture, as they were known, had done earlier. Kostrzewski had just been forced into early retirement by the communist authorities and he must have felt great satisfaction translating Clark's work into Polish" (Clark 1957; Lech 20I0: I7I-I72; cf., Kostrzewski 1970: 283-284).

By the end of his first year at Cambridge, Coles had become interested in Palaeolithic cave paintings as well as stone tools. For this reason, in the summer of 1956 , he decided to learn about cave art where it is represented the best - in France and Spain. His friend Charles McVean accompanied him on his travels. He was able to participate in Professor André Leroi-Gourhan's (I9II-1986) excavations in Arcy-sur-Cure in France (June-July 1956). Those were John's first well-organised and exemplarily-conducted excavations and he learned a lot (Coles 2019: 22). They were followed by visits to famous caves with Palaeolithic paintings and carvings: Lascaux, Les Combarelles, Niaux, Cantabrian Altamira, Pindal, Castillo and others. The adventures he had along the way as well as the return journey through Brittany, where he studied the famous megalithic ceremonial complex during his stay in the Carnac region, were depicted with great sense of humour. Here is the shortened description of one adventure:

"As we approached the Breton landscape, one early evening, we came up behind a small van, in the open back of which were two Frenchmen in their country clothes. They sat on boxes and were smoking. We followed them along and one of the men reached down and proffered a small fish to 
us. We nodded yes and he chucked it at our windscreen. Others soon followed and as fast as McVean could gather in, as I was attempting to drive through the fish-smeared glass, he passed them back to our female companion, and more and more of the fish splattered onto the car... We camped and had fine feast of fried fish, and we three were then ill all night" (Coles 2019: 26).

Dr McBurney was supportive of John's interest in researching the painted caves of the Palaeolithic, and he had his own interest in research on the Palaeolithic deposits in caves in Great Britain. They went on a tour of caves in England and Wales, which proved to be somewhat chaotic. As a consequence, John gave up the intention of pursuing a doctorate in the Palaeolithic to focus on a different period instead. Looking for a new topic and a supervisor, he visited Oxford, where he was to meet with Professor Christopher Hawkes (1905-I992), a leading exponent of the West European Iron Age. Hawkes was absent, but at the entrance to the Ashmolean Museum, John ran into Professor Stuart Piggott (I9IO-I996), Abercromby Professor of Prehistoric Archaeology in the University of Edinburgh (Fig. 2). This led to another meeting in Edinburgh and the decision to study for a PhD (doctorate) at the Department of Archaeology in Edinburgh University. Piggott suggested the Late Bronze Age of Scotland as the subject of John's research, which the candidate accepted with some hesitation as he was not familiar with the subject, although it seemed promising (Clark I989: 63-64; Coles 2019: 29).

This first Scottish episode in John's scientific life lasted from I957 to I960, during which time he lived in Edinburgh and conducted extensive research on the collections of the National Museum of Scotland and other cultural establishments. He was elected to the Society of Antiquaries of Scotland, and he published his first articles on the Scottish Late Bronze Age in the society's Proceedings (Coles and Livens I960; Coles I96I; I962a). Then came an article on European Bronze Age shields published in Proceedings of the Prehistoric Society (Coles I962b). Alongside his studies, he continued to play tennis, with considerable success.

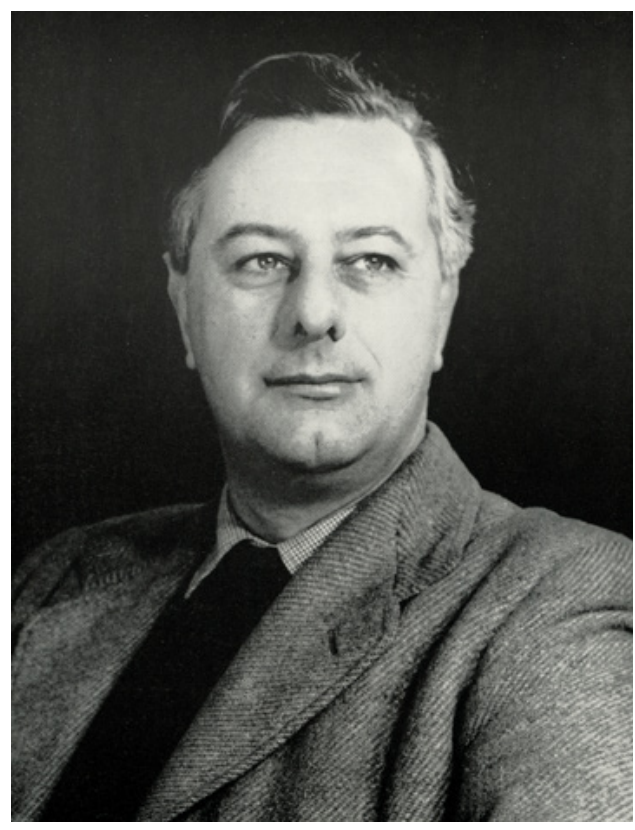

Fig. 2. Stuart Piggott (1910-1996). Photo: M. J. Murray. After J. M. Coles and D. D. A. Simpson (eds), Studies in Ancient Europe. Essays presented to Stuart Piggott. Leicester, University Press 1968. 
I6o $\mid$ Danuta Piotrowska and Wojciech Piotrowski

Working with Piggott led to a life-long friendship for the two of them. At the very beginning, the eminent scholar offered John the opportunity to visit together museum establishments in the north of Scotland, where they studied collections, often scattered, of artefacts of the Bronze Age. The archaeological journey in the company of Piggott was "probably the most beneficial and certainly the most entertainingly instructive" (Coles 2019: 32), and filled with unexpected adventures, for example:

"We searched through various boxes that lay amidst the museum furniture... One socketed axe could not be found and I was insistent that it should be somewhere amidst the dismantled collection. I found it, inside the half-opened jaws of stuffed alligator that lay on the floor" (Coles 2019: 34).

In August of 1959, John submitted his $\mathrm{PhD}$ to the University, but was told it was too soon, he could not submit until he had completed at least two years of research. He re-submitted a couple of months later. His examiners were Terence G. E. Powell (1916-1975) and Stuart Piggott. Powell, like Coles, had an interest in prehistoric art (Powell 1966), and they became good friends. And, as we learned from Bryony Coles: "Also in 1959 John was awarded the Scottish Tennis Cup".

The relationships John formed in Scotland, especially with Stuart Piggott, stood the test of time. As a token of his respect and gratitude to his senior colleague, supervisor and friend, he co-edited (Coles and Simpson eds 1968) a book beautifully delivered by Leicester University Press. It contains the essay Ancient man in Europe (Coles 1968a), as part of research for a book devoted to the Palaeolithic (Fig. 3a) that he was working on at the time (Coles and Higgs 1969; 1975).

In later years, as John pursued his academic career, he often returned to Scotland as an invited guest, an advisor on excavations, a lecturer at Scottish conferences or delivering lectures to the general public. He was an outstanding promoter of archaeology, and from 1992 to 2002 he served as a member of the Royal Commission on the Ancient and Historical Monuments of Scotland.

Having returned to Cambridge in 1960, John devoted much of his time to teaching students at the Department of Archaeology. He had not suspected how time consuming it would be, although looking back he admitted that the time between 1960 and 1980 was also filled with intense activity outside the didactic work (Coles 2019: 45-57). At the same time, he had become engaged in the increasingly complex fields of wetland, environmental and experimental archaeologies (Coles 1963a; 1973; 1976). Bursting with energy, he always maintained a positive outlook on people and the world around him (Fig. 3b, c; cf., 3e). He was made a Fellow of Fitzwilliam College in Cambridge in 1963 and he retained his connection with the college for the rest of his life. At his passing, the following message appeared on the Fitzwilliam website: "As a public mark of respect, we flew the College Flag at half-mast on Monday I9 October". 

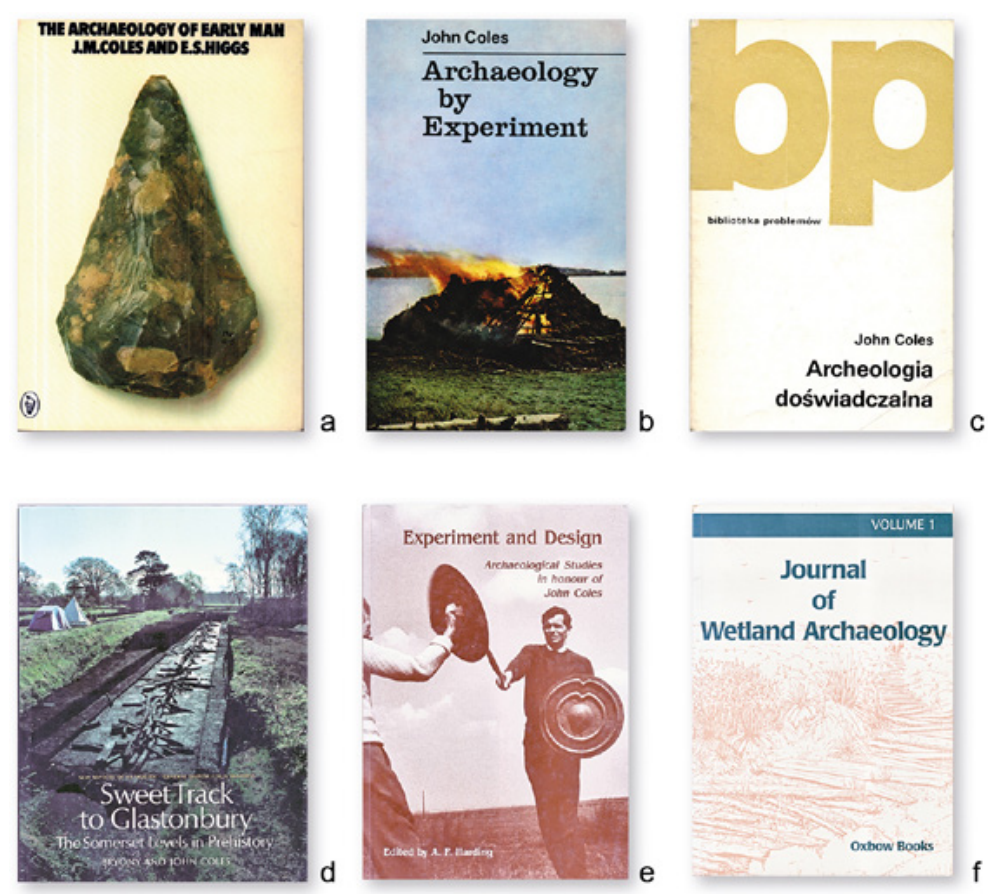

Fig. 3. Covers of some of the publications mentioned in the article and related to John Coles' archaeological activity:

a - J. Coles and E. S. Higgs, The Archaeology of Early Man, Harmondsworth 1975: Penguin Books

(2nd edition); b - J. Coles, cover of his first book on experimental archaeology, London 1973:

Hutchinson and Co. Ltd; c - J. Coles, Archaeology by Experiment in the Polish edition, Warsaw 1977: Państwowe Wydawnictwo Naukowe; d - B. Coles and J. Coles, Sweet Track to Glastonbury. The Somerset Levels in Prehistory, London 1986: Thames \& Hudson. Winner of Archaeological Book of the Year Award; e - A. F. Harding (ed.), Experiment and Design. Archaeological Studies in Honour of John Coles, Oxford 1999: Oxbow Books, on the cover - John Coles and Don Allan illustrating the techniques of Bronze Age combat. Photograph by Ralf Crane, 1963. (OTime/Life; $\mathrm{f}$ - cover of the first volume of Journal of Wetland Archaeology, edited by T. Brown, B. Coles, S. Rippon and R. Van de Noort, Oxford 2001: Oxbow Books.

Between 1960 and 1980, he progressed at Cambridge University from Assistant Lecturer to Lecturer to Reader in Archaeology, and between 1980 and 1986 he was Professor of European Prehistory. In 1978 he was elected to the British Academy, the foremost institution for the Humanities. He published a number of books aimed at students, notably The Archaeology of Early Man (Coles and Higgs 1969; 1975) which was read by generations of students (Fig. 3a), as was Field Archaeology in Britain (Coles 1972). Together with Anthony Harding, whose PhD he had supervised, he wrote and published a highly regarded work The Bronze Age in Europe (Coles and 
I62 Danuta Piotrowska and Wojciech Piotrowski

Harding 1979). Through all these years he was teaching, alongside being active in the field of archaeology and publishing the results of his research, which dealt with a vast range of topics (Coles 1982; Coles B. et al., 1999).

In Yesterday's Man John described the time (1967-1968) the Prince of Wales spent at Trinity College, naturally in his characteristically poignant and detached manner. The interested reader will undoubtedly find the original passage very rewarding (Coles 2019: 74-79).

Relatively early in his career, John became interested in experimental archaeology. The beginnings can be traced to a short article on the subject published in the weekly Illustrated London News (Coles 1963c). He devoted a great deal of attention to this field in subsequent years (Coles 1968b). Two of his books introduced a wide range of people to this subject that was often under-appreciated, but in John's eyes had great potential for yielding new insights for the understanding of archaeological evidence (Coles 1973; 1979). John tested the musical capabilities, so to speak, of prehistoric bronze horns from the collection in the National Museum of Ireland in Dublin (Coles 1963b), he conducted experiments with replica Bronze Age shields, made of bronze and leather (Fig. 3e), as well as ancient techniques of using flint, stone and bronze axes, during his time in Scotland and Cambridge, and over the course of his research in the Somerset Levels. The first of his books on the subject (Fig. 3b) was translated into Polish (Fig. 3c) by Dr Maria Miśkiewicz (Coles 1977). It should be noted that John devoted a great deal of attention to music (Coles 1973: 158-167; 1977: 224-238; 1978).

John cooperated with Peter J. Reynolds (1979), another important figure in the field of experimental archaeology, who developed the Butser Ancient Farm, in Hampshire. Together with his students, John regularly took part in experiments at Butser, at West Stow in Suffolk (woodworking and reconstructions of Anglo-Saxon houses), and at Middlesex Polytechnic - the art and craft of metal-working in copper and bronze (Coles 2019: 59-62). The underlying principles that he established concerning the field of experimental archaeology remain basically unchanged to this day (Coles 1997b). It is a noteworthy fact, especially as today the term experimental archaeology is quite often confused with archaeological re-enactment.

An important chapter in John's curriculum vitae relates to wetland archaeology. The field has developed in Europe since the study of the Swiss Bronze Age palafites in Obermeilen by Ferdinand Keller in 1854 (Coles 1997-1998: 288-289; Trigger 2007: 134), for example with Hans Reinerth's work around the Federsee basin, published in Die Wasserburg Buchau (Reinerth 1928; Coles 1997-1998: 289; Schöbel 2006) and Józef Kostrzewski with Zdzisław A. Rajewski on the wetland Lake Biskupin peninsula (Coles 1997-1998: 30I-302; Piotrowska 1997-I998; Piotrowski 1998; Brzeziński and Piotrowska 20I2: 30-36). Such investigations and publications were of great importance, and John's earlier 2oth century predecessors made significant advancements in this area of archaeology. 
In the later 2oth century, Professor John Coles and his wife Professor Bryony Coles (née Orme) can be seen as pioneers of modern, comprehensive and interdisciplinary research on wetland sites (Coles and Orme 1980). From his time as a student at Cambridge, John was familiar with the results of Grahame Clark's excavations at Star Carr, and in the 1960s, encouraged by Clark, he began work in the Somerset Levels, excavating several brushwood trackways, and in 1966 he identified a substantial wooden track, known as The Abbot's Way (Coles 2019: 63).

In 1970 a new trackway was discovered by Ray Sweet, one of the peat diggers, and named the Sweet Track by John. It proved to be a very significant structure, and led to the initiation of the Somerset Levels Project in 1973, set up by John and Bryony together with palaeobotanist Alan Hibbert and Dr Geoff Wainwright from the Department of the Environment. The results from the long-term Project had a ground-breaking significance (B. and J. Coles 1986). It was carried out from Cambridge University, Department of Archaeology and University of Exeter, Department of History and Archaeology. Between 1975 and 1989 John was the editor of Somerset Level Papers, which reported annually on the research in the Levels. The already-cited book, Sweet Track to Glastonbury (Coles B. and Coles J. 1986) was a winner of the Archaeological Book of the Year Award (Fig. 3d). The work of John and Bryony Coles in wetlands in many different parts of the world (Coles J. M. and Coles B. J. I989), their dedication and fruitful collaboration with their colleagues as well as exponents of other natural sciences, allowed the development of a multifaceted enterprise. Such an approach to archaeology was becoming more frequent, and today is almost universal. This was a continuation of the tradition referred to by P. J. Smith (2009: 39-68) as "Grahame Clark's New Archaeology" and developed by him at Cambridge in collaboration with "Men in White Coats".

John never gave up on trans-regional wetland problems (Coles and Lawson 1987; Coles B. J. and Coles J. 1989), and using the Somerset Levels Project as an example, he was the instigator of major wetland surveys (Figs $3 \mathrm{~d}$ and 4 ), funded by English Heritage, in other regions of England, in the East Anglian Fens, the Humber Wetlands, and North West Wetlands (Coles and

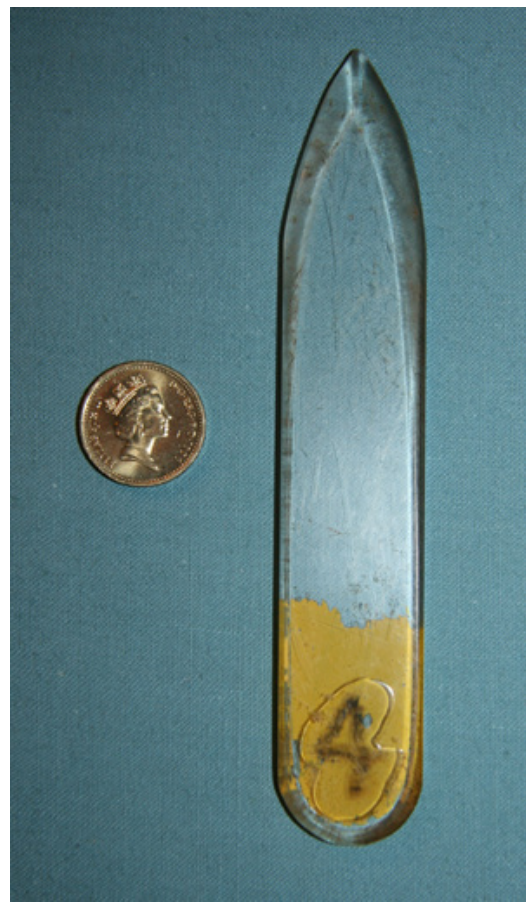

Fig. 4. Special tool used during exploration activity on the Somerset Levels site. Professor J. Coles' gift to Wojciech Piotrowski. Photo by J. Lech. 
I64 Danuta Piotrowska and Wojciech Piotrowski

Hall 1998; Coles 2002; 2019: 95-96). In 1984 his influential book The Archaeology of Wetlands (Coles 1984) was published, and his views also later appeared in Archaeologia Polona (Coles 1997-1998). He often emphasized the importance of matters pertaining to waterlogged wood preservation (Coles i990b).

John expressed clearly his notion of wetland archaeology in WARP Occasional Paper Number I:

"The purpose of wetland archaeology must be to expand our knowledge of the past. For too long, dryland archaeology has dominates our thoughts. We should stop trying to fill gaps in our existing knowledge by continuing to practice traditional dryland, repetitive archaeology, and we should attempt to enlarge the whole basis of our information, to extend the frontiers, by innovative wetland expansive archaeology... Wetlands can provide a totality of evidence, unscavenged, of closely definable time-scales, which can obtain from no other source in northern latitudes apart from a few frozen sites" (Coles 1987: 242).

WARP, the Wetland Archaeology Research Project, was established by John and Bryony Coles in 1987, with its base at the University of Exeter. The newsletter of WARP, called NewsWARP and edited by John until late 2002, was published under the auspices of the project. Most of the conferences organized by WARP all over the world have been published in WARP Occasional Papers, with more wide-ranging issues alongside more general studies (for example Coles and Coles 1996). At the beginning of this century, the membership of WARP included more than 300 associates and about 50 institutions from around 30 countries (Coles 200I: vii-viii). John was in close cooperation with the first editors of Journal of Wetland Archaeology (first vol. in 200I) (Fig. 3f) - Tony Brown, Bryony Coles, Stephen Rippon and Robert Van de Noort (Coles 20ora: 3-13). Now, the Journal is edited by Dr Ben Gearey of University College Cork in the south of Ireland, while Dale Croes, Director of the Pacific Northwest Archaeological Society and Services, has developed an on-line presence for News WARP.

The creation of WARP enabled the development of international connections (Coles I99I), the organizing of joint conferences, mutual consultations, student exchange, and it fostered advancements in environmental studies and its popularisation (for example, Minnitt and Coles 1996), as well as supporting local museums. In the case of Somerset, John and Bryony's activity in the field of wetland archaeology have become something of a scientific and cultural hallmark of the region. In 1993 John Coles became an Honorary Professor at Exeter University. Among wetland archaeology researchers the world over, he will be remembered as a unique figure, which is reflected in his introductory articles for publications dealing with complex issues in the field (Coles 1988; 1998; 200rb).

Alongside his core activity in the field of wetland archaeology, between 1974 and 2005 John was researching Scandinavian rock carvings. His interest was supported by his friend Bo Gräslund from Uppsala University and later also by Lasse Bengtsson and Stephen Minnitt (Coles 20I9: I09-IIO). John's research and his way of documenting the 
images inscribed into rock outcrops in Sweden and Norway led to a different perception of Bronze Age art in the region (Coles 1995). His work in this field resulted in publications of major importance: Images of the Past (1990a), The Rock Carvings of Uppland (1994), Patterns in a Rocky Land (2000) and Shadows of a Northern Past (2005). They are regarded as textbooks, both for professionals as well as reaching a broader audience.

During his research on Scandinavian rock carvings, John was admired for his sense of direction in the rocky terrain, strewn with local roads. He could memorize a map after having one look at it. When navigating the area on foot or by car, he always seemed to find the right rock formation with prehistoric carvings. He was very popular and made many friends among his Swedish and Norwegian colleagues. He was also a particular friend of the Department of Archaeology and Ancient History of Uppsala University. His obituary on the university's website (www.arkeologi.uu.se) is a testimony to the popularity and respect he enjoyed there. His poems devoted to rock carvings (Coles 2019: II2-II3) demonstrate his emotional attachment to the subject. In 2009 he was awarded an honorary doctorate by Uppsala University and a prize for excellence from the Royal Swedish Academy of Letters, History and Antiquities.
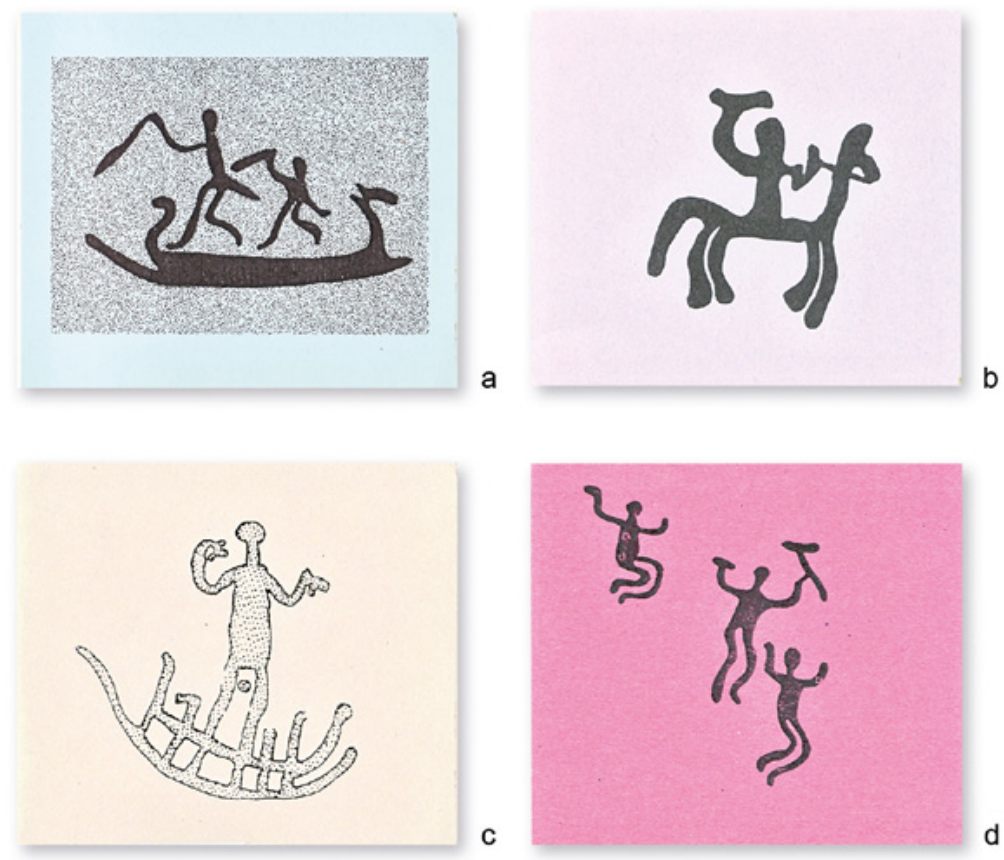

Fig. 5. Selection of holiday cards sent to the authors by John and Bryony Coles. Drawings of the Scandinavian (Sweden, Bohuslän province) rock engravings by John Coles: $\mathrm{a}$ - Backa; b - Tanum parish; c - Hogdal; d - Torp. 
I66 | Danuta Piotrowska and Wojciech Piotrowski

Over the years of our correspondence, John and Bryony sent us holiday postcards, often adorned with John's drawings with motifs from prehistoric Scandinavian rock art (Fig. 5). Professor Aidan O'Sullivan's memorial (2020: 9) indicates that others also received John's small pieces of art.

From the very beginning of his time at Cambridge, thanks to Grahame Clark, John participated in editorial work on the Proceedings of the Prehistoric Society. Brian Fagan (200I: 185), a student at Cambridge University and today Professor Emeritus of Anthropology at the University of California, Santa Barbara, emphasized that:

“...Clark's lifelong concern was with the Prehistoric Society. His record of attendance at meetings was virtually continuous, his editing of the Proceedings by this stage an integral part of his professional life. John Coles, then assistant editor, recalls editing and completely rewriting papers with Clark as they travelled to and from London in the train".

Between 1970 and 1979, John was Editor of this renowned archaeological journal, which provided him with the opportunity to collaborate with some of the most eminent scholars of that time, and from 1978 to 1982 he served as President of the Prehistoric Society. Later in his career, he established the 'John and Bryony Coles Bursary (Student Travel Award)' to help student members of the Society to travel abroad.

John received a number of medals and other honours in Britain and abroad, in addition to those already mentioned. They include Honorary Memberships of the Institute of Field Archaeologists (1991) and the Society of Antiquaries of Scotland (2000), and the Royal Irish Academy (2005). He was awarded the Grahame Clark Medal of the British Academy (1995), the Gold Medal of the Society of Antiquaries (2002), the European Archaeology Heritage Prize (2006), and the Rajewski Medal of the State Archaeological Museum in Warsaw (2007).

To this day, we are left wondering, how was it possible that John could remain so active in various fields of archaeology and still be able to help colleagues at home and abroad. We have already mentioned Scotland. But Ireland was no less important. Prof. Aidan O'Sullivan (2020: 9) recalls:

"He was a strong supporter of archaeology in Ireland, acting as External Examiner in University departments in Dublin, Galway and Cork. He encouraged the development of wetlands archaeology here and was a friend of Prof. Barry Raftery... John was an Honorary Member of the Royal Irish Academy in Ireland".

He was also a highly regarded advisor dealing with wetland archaeology all over the world. As mentioned above, he was awarded the European Archaeological Heritage Prize, and truly one can hardly think of a more worthy recipient. 
One must also mention John's and Bryony's connection to Poland. It all began in 1984. The exhibition "Biskupin: Poland's Iron Age Lake Village" prepared by the Biskupin Museum, a Department of the State Archaeological Museum in Warsaw, was on its United Kingdom tour. Following shows in the Weald and Downland Open Air Museum in Singleton, the Norton Priory Museum in Runcorn, the Museum of Archaeology in Durham and Edinburgh University Library, from November ist, the exhibition was on display at the University Museum of Archaeology and Anthropology in Cambridge (Piotrowski 1985). This is where I [W. Piotrowski] met Professor John Coles, who presented me with the Polish edition of his first book on experimental archaeology (Coles 1977), with an appropriate dedication.

Over the course of various archaeological projects in Biskupin, three years later we realized how beneficial it would be for our wetland site to be able to take advantage of John and Bryony Coles' knowledge. They accepted our invitation and arrived in Biskupin in August 1989. Their short stay allowed our guests to familiarise themselves with the basic problems of the site, to visit the Neolithic burial complex with long barrows in Wietrzychowice and to take a ride on the narrow gauge railway from Biskupin to Żnin. We agreed to continue our cooperation and John became our advisor on wetland archaeology. A year later W. Piotrowski took part in a WARP conference devoted to waterlogged archaeological wood organised by John and Bryony together with Mike Dobson (Coles J. et al., 1990; Piotrowski 1990).

On April 5-7 199I, at the University of Exeter, the Prehistoric Society and WARP held an international conference "The Wetland Revolution in Prehistory", organized by John and Bryony. More than 20 speakers from all over the world (including Poland) presented the problems and successes of wetland archaeology in their countries (Piotrowski 199I-1992; Coles B. 1992), making it a truly stimulating meeting. In the summer of the same year, the State Archaeological Museum in Warsaw, with its Department in Biskupin, invited John and Bryony to come to Poland once more. Their visit proved very fruitful for the Lake Biskupin peninsula and its prehistoric remains. Under the guidance of and with active participation of our English friends, we managed to install the first monitoring tubes within the waterlogged layers of the site (Figs 6 and 7). This was the beginning of the Biskupin monitoring complex, later developed by Dr Leszek Babiński of the Biskupin Conservation Waterlogged Wood Laboratory. Later on came an excursion to Izdebno, the aim of which was to familiarise our guests with the big fortified settlement erected by the Lusatian Culture community. We then travelled to a swamp/bog area in the Biebrza river basin and the town of Łomża, where Bryony went beaver spotting by the Narew river (Fig. 8), and to Białowieża Primeval Forest and the towns of Ciechanowiec, and Nowogród on Bug river, the island on Lednica Lake known as Ostrów Lednicki with its ruins of the first seat of the rulers of Poland and an early medieval fortified settlement (we were given a guided tour by our colleague Jacek Wrzesiński), and Łekno, with remains of 
I68 Danuta Piotrowska and Wojciech Piotrowski

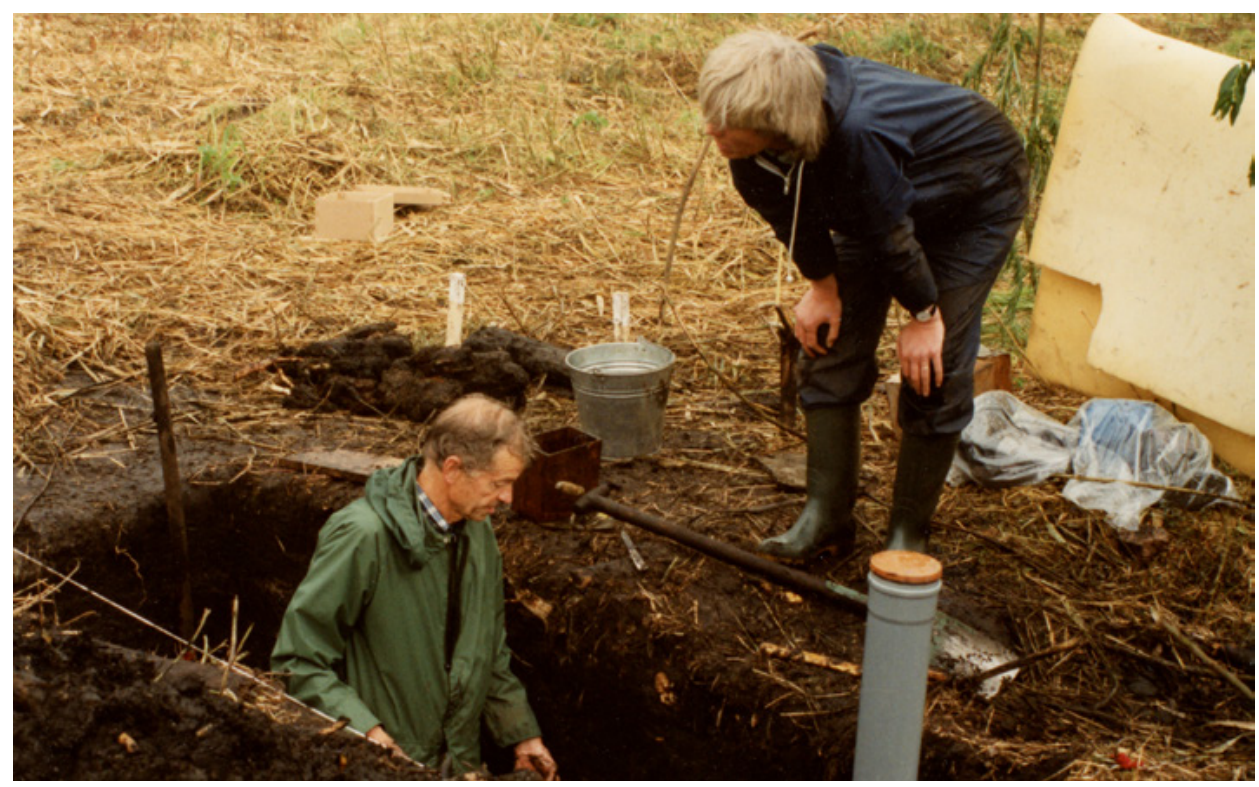

Fig. 6. Biskupin 1991. The remains of the fortified settlement of the Lusatian Culture, site 4. John and Bryony Coles inserting monitoring tubes. Photo by W. Piotrowski.

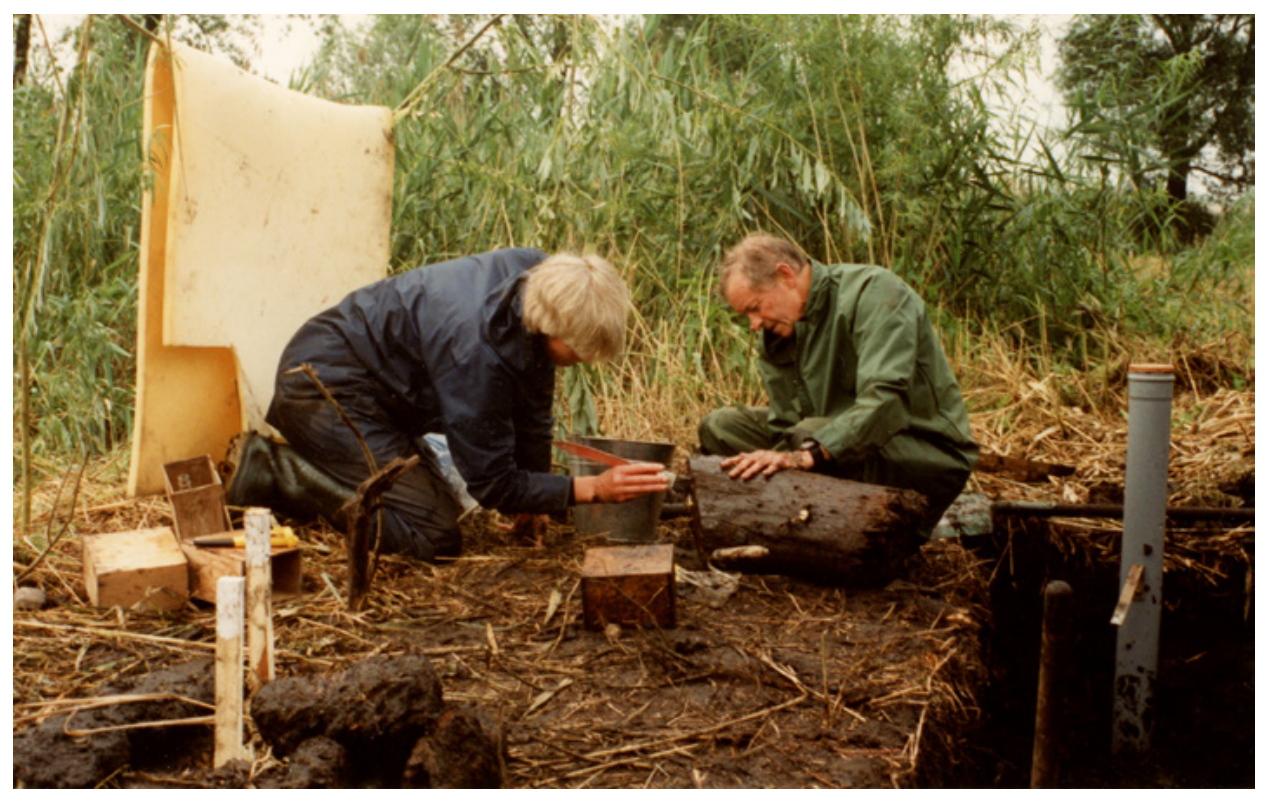

Fig. 7. Biskupin 1991. The remains of the fortified settlement of the Lusatian Culture, site 4. John and Bryony Coles taking samples of archaeological waterlogged wood. Photo by W. Piotrowski. 


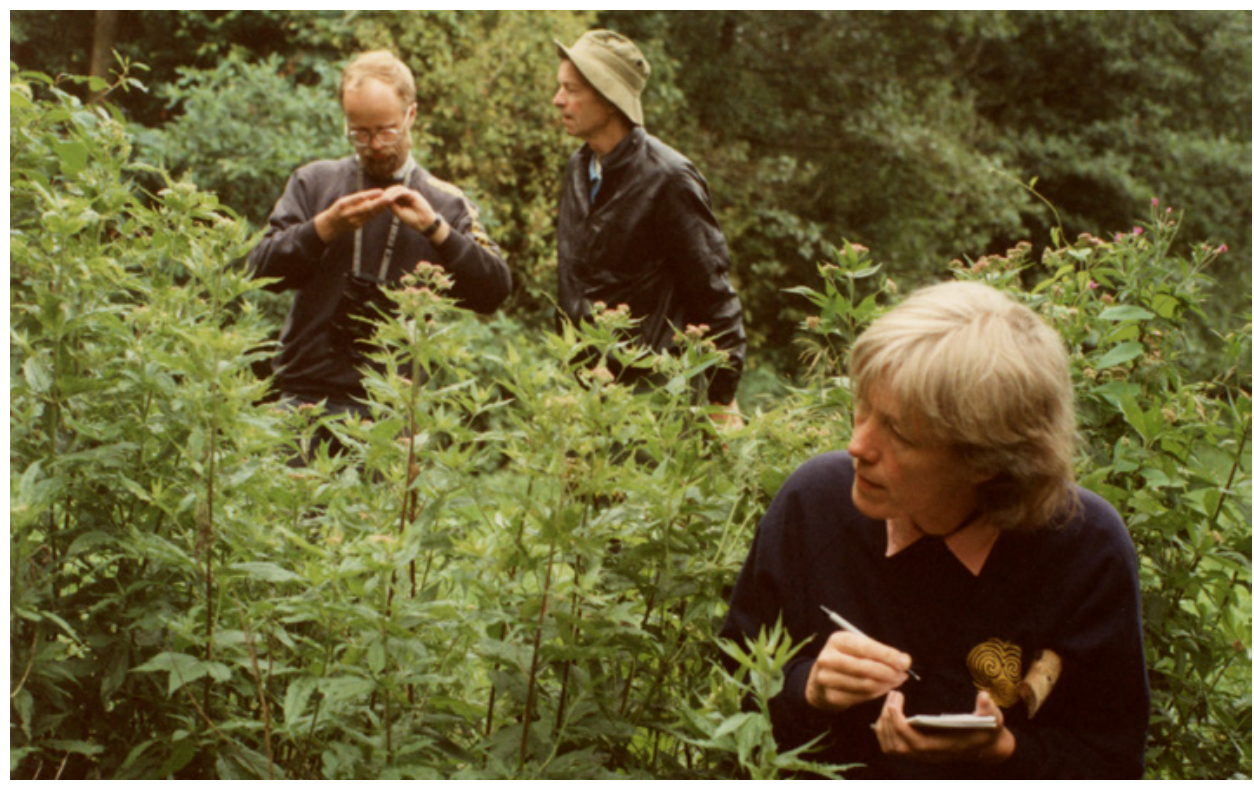

Fig. 8. Environs of Łomża town, (NE Poland) 1991. The Narew river. Bryony and John Coles spotting beavers. Photo by W. Piotrowski.

an early medieval stronghold and the oldest Cistercian abbey in Greater Poland (II53), where we were cordially received by Dr Andrzej Marek Wyrwa and members of his excavation team (Figs 9 and Io). This way new friendships were formed.

In April of 1997, to mark the 65th birthday of John Coles, a conference titled From Somerset to Simris was organized in Exeter by Professor Anthony Harding, with the active participation of the Prehistoric Society. Representatives of the Biskupin Museum (W. Piotrowski and W. Zajączkowski) presented him with a birthday present of a replica of a Bronze Age sword, which was met with great applause from the participants (and Bryony reports that John later had difficulty keeping it out of the hands of one young member of the family). The conference resulted in the publication of Experiment and Design. Archaeological Studies in Honour of John Coles, (see Fig. 3e), edited by the organizer of the conference, John's friend and former student Professor Anthony F. Harding (1999).

Between September 13th and 21st 1997, the third Biskupin Archaeological Festival took place - Man and woman in the Past - with John and Bryony Coles as guests of honour. They took part in the British Day (Fig. II) and in the evening they delivered a lecture dedicated to wetland and experimental archaeology. John addressed issues in wetland archaeology around the world, the basis for the article already mentioned above, written for Archaeologia Polona (Coles 1997-1998). 


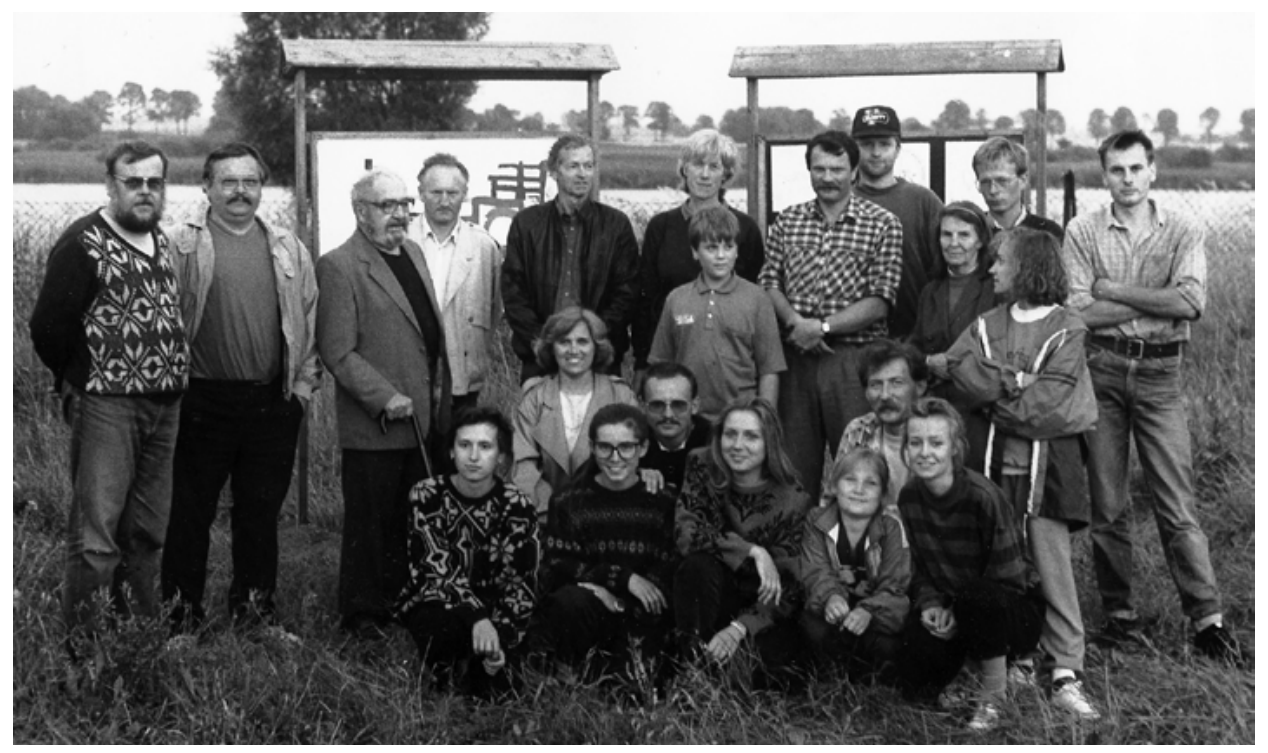

Fig. 9. Łekno (NW Poland) 1991. Early medieval settlement complex. From left, Dr A. M. Wyrwa director of the archaeological excavations; John and Bryony Coles in the middle. Photo by P. Namiota.

From the archives of the "Łekno" Archaeological Expedition.

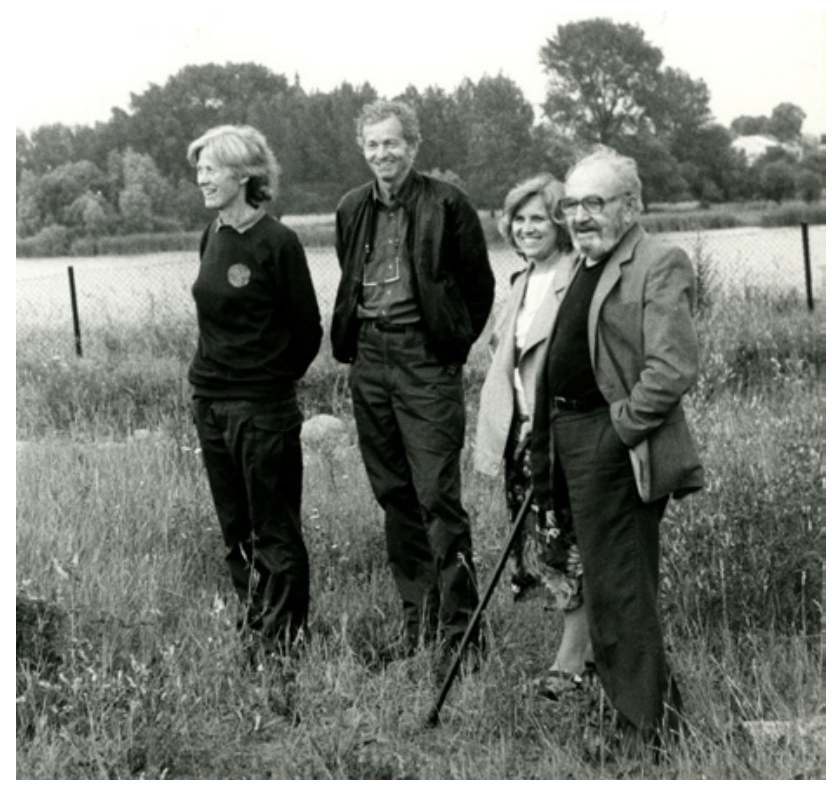

Fig. 10. Łekno (NW Poland) 1991. Early medieval settlement complex. From left, Bryony and John Coles, Danuta Piotrowska and Walenty Szwajcer discoverer of the prehistoric site at Biskupin in 1933. Photo by P. Namiota. From the archives of the "Łekno" Archaeological Expedition. 


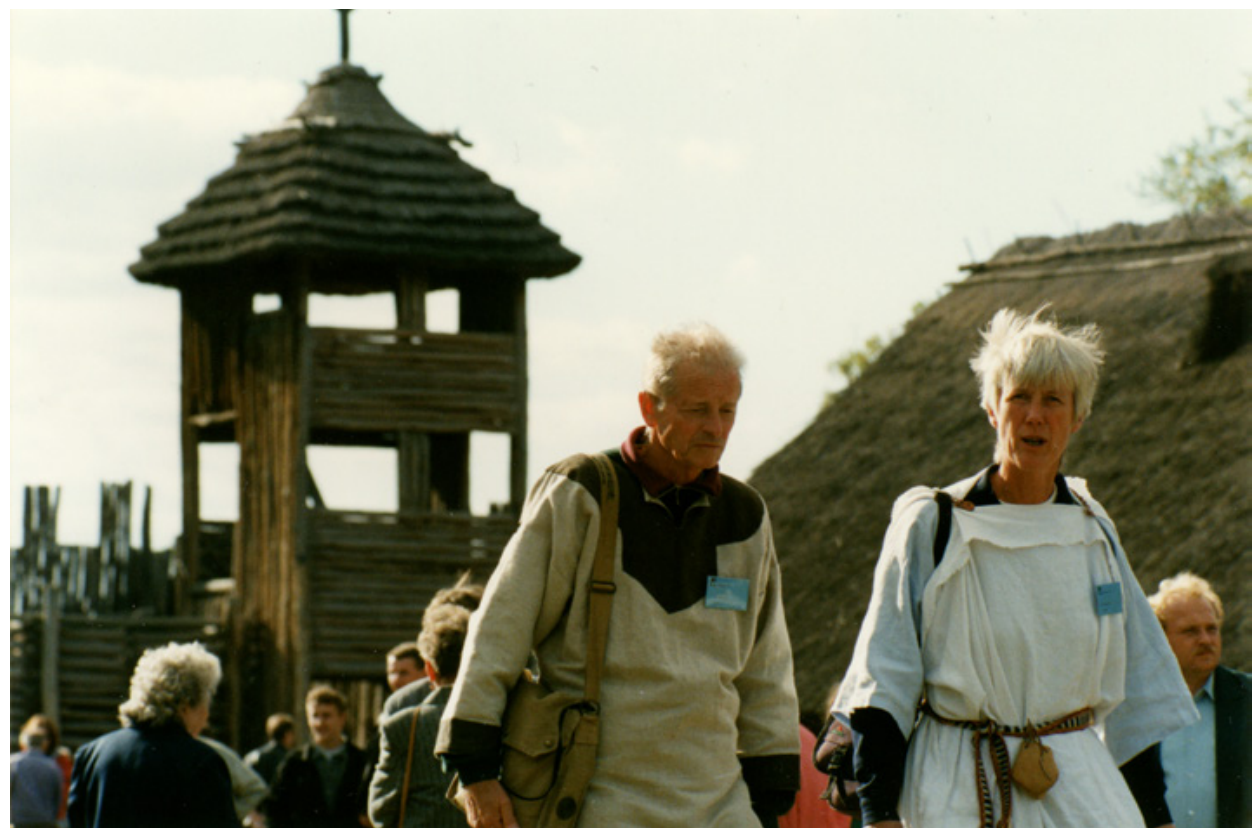

Fig. 11. Biskupin, 20 September 1997. The British Day. John and Bryony Coles as special guests of the 3rd Archaeological Festival Man and Woman in the Past (13-21 September). Photo by W. Piotrowski.

For the next ten years, we kept up correspondence, discussing wetland archaeology and the conservation of waterlogged wood, and when one of us worked on papers for an issue of Archaeologia Polona in English, John was kind enough to provide stylistic revisions of the English translations (Piotrowska 1997-1998: 28I; 2004: 286).

On 23-25 May 2007, the International Symposium The history of archaeology and archaeological thought in the 2oth century, dedicated to Professor Grahame Clark on the centenary of his birth, and on the 5oth anniversary of the Polish edition of Clark's Prehistoric Europe: the economic basis, was held at the Archaeological Museum in Biskupin (Piotrowska and Piotrowski 2009). Prof. John Coles was the Honorary Chairman of the Symposium Organization Committee. He arrived with Lady Mollie Clark, Professor Clark's widow and their son Philip. Our guests received a medal commemorating Professor Rajewski, presented by Dr W. Brzeziński, director of the State Archaeological Museum in Warsaw (Piotrowska and Piotrowski 2009: 257; Lech 20IO: 177-I79). John and Bryony Coles were among the eminent speakers. John delivered the opening lecture Grahame Clark, Cambridge and the World, and Bryony the lecture Grahame Clark and the Stone Age Hunters. The results of the Symposium were published as Grahame Clark and His Legacy (Marciniak and Coles 
I72 Danuta Piotrowska and Wojciech Piotrowski

eds 20IO), including, among others, a paper by John dedicated to Grahame Clark (Coles 20I0).

Professor John Coles was an archaeologist of broad interests and outstanding achievements in various disciplines of British, European and world archaeology. $\mathrm{He}$ was involved in prehistory from the Palaeolithic to the Iron Age. Although experimental archaeology had been long practised in Great Britain, he shaped it through his works into a major specialisation in prehistoric research (Coles 1973; 1979; cf., Renfrew and Bahn I991: 45 and 286-287). With his wife Bryony he contributed to wetland archaeology, which became one of the key concepts in archaeology globally. He also had numerous important achievements in the studies of the Bronze Age, prehistoric art and environmental archaeology.

The symposium in Biskupin in 2007 was the last time we saw John and Bryony Coles, although we later stayed in touch. John received and reviewed Prolegomenon on the Archaeology of Biskupin. Volume I. An Archaeological Bibliography of Biskupin 1933-1983 (Coles 2009), not to mention the exchange of many letters and postcards (Figs I2 and I3).

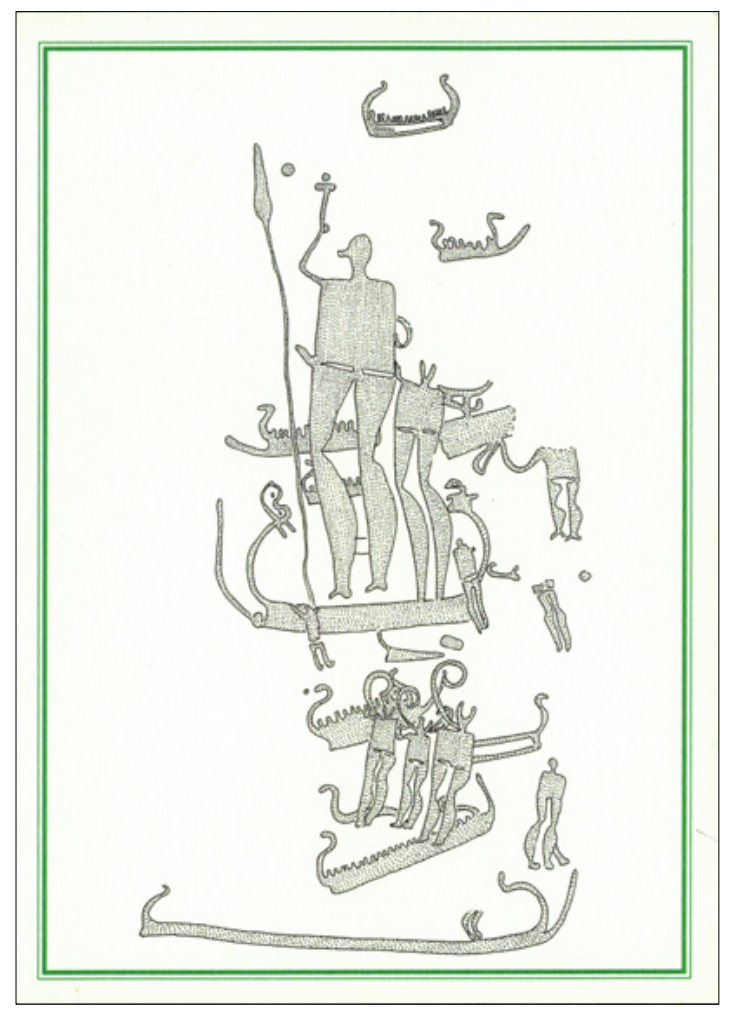

Fig. 12. Holiday card from John and Bryony sent to the Authors of this article with John`s drawing of rock-carving at Kalleby, Bohuslän, Sweden. 


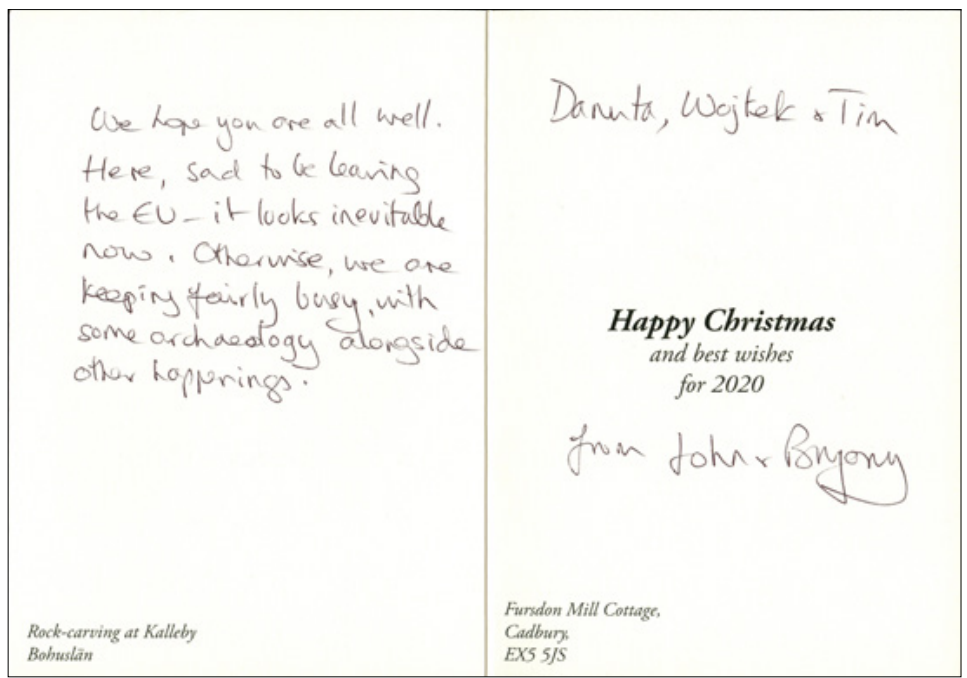

Fig. 13. Holiday card from John and Bryony sent to the Authors of this article with Christmas 2019 greetings and best wishes for 2020 .

The message from Bryony about John's passing on 14 October 2020 in his Fursdon Mill Cottage, Devon, affected us greatly. Thank you, dear John, for your friendship. You live on in our memory.

\section{ACKNOWLEDGEMENT}

We are profoundly grateful to Professor Bryony Coles for information about John that was used in this article.

Translated by Tymoteusz Piotrowski

\section{REFERENCES CITED}

I. The most important publications by John Morton Coles, written by Him or written and edited by Him together with another researchers.

Coles, B. and Coles, J. 1986. Sweet Track to Glastonbury. The Somerset Levels in Prehistory. London, Thames and Hudson. 
I74 Danuta Piotrowska and Wojciech Piotrowski

Coles, B. J. and Coles, J. 1989. People of the Wetlands. Bogs, Bodies and Lake Dwellers. London, Thames and Hudson.

Coles, B., Coles, J. and Schou Jørgensen, M. (eds). 1999. Bog Bodies, Sacred Sites and Wetland Archaeology. Exeter, WARP Occasional Paper I2.

Coles, J. M. 1962a. Scottish Late Bronze Age metal work. Proceedings of the Antiquaries of Scotland 93, 1959-60: 16-134.

Coles, J. M. 1962b. European Bronze Age shields. Proceedings of The Prehistoric Society 28: 156-190.

Coles, J. 1963a. Environmental studies in archaeology. In D. Brothwell and E. S. Higgs (eds), Science in Archaeology. A comparative survey of progress and research, 93-98. London, Thames and Hudson.

Coles, J. 1963b. Irish Bronze Age horns and their relationship with northern Europe. Proceedings of the Prehistoric Society 29: 326-356.

Coles, J. M. 1968a. Ancient Man in Europe. In J. M. Coles and D. D. A. Simpson (eds), Studies in Ancient Europe. Essays presented to Stuart Piggott, 17-43. Leicester, Leicester University Press.

Coles, J. M. 1968b. Experimental archaeology. Proceedings of the Society of Antiquaries of Scotland 99 (1966-67): I-20.

Coles, J. M. 1972. Field Archaeology in Britain. London, Methuen.

Coles, J. M. 1973. Archaeology by Experiment. London, Hutchinson and Co. Ltd.

Coles, J. M. 1978. Music of Bronze Age Europe. Archaeology 3I: I2-2I.

Coles, J. M. 1979. Experimental Archaeology. London, Academic Press.

Coles, J. M. 1982. The Bronze Age in North-western Europe: problems and advances. Advances in World Archaeology I: 265-321.

Coles, J. M. 1984. The Archaeology of Wetlands. Edinburgh, Edinburgh University Press.

Coles, J. M. 1987. Precision, purpose and priorities in wetland archaeology. WARP Occasional Paper Number I. Reprinted from The Antiquaries Journal, vol. LXVI, part II: 227-247.

Coles, J. M. 1988. A wetland perspective. In B. A. Purdy (ed.), Wet Site Archaeology, I-I4. Caldwell, New Jersey, The Telford Press.

Coles, J. M. 1990a. Images of the Past. A guide to the rock carvings and other ancient monuments of northern Bohuslän. In association with Lasse Bengtsson. Bohuslän, Bohuslän Museum.

Coles, J. M. 1994. Rock Carvings of Uppland: A Guide. Uppsala. Occasional Papers in Archaeology 9.

Coles, J. M. 1995. Rock art as a picture show. In K. Helskog and B. Olsen (eds), Perceiving Rock Art. Social and Political Perspectives, I8I-I99. ACRA, the Alta conference on rock art. Oslo, Novus forlag: Instituttet for sammenlignende kulturforskning.

Coles, J. M. 1997. John Grahame Douglas Clark, 1907-1995. Proceedings of the British Academy 94: 357-387.

Coles, J. M. 1997-1998. Wetland archaeology in the 2oth century: history and commentary. Archaeologia Polona 35-36: 287-317.

Coles, J. M. 1998. Prologue: Wetland Worlds and the Past Preserved. In K. Bernick (ed.), Hidden Dimensions. The Cultural Significance of Wetland Archaeology, 3-23. Vancouver, UBC Press.

Coles, J. M. 2000. Patterns in a Rocky Land. Rock Carvings in South-West Uppland, Sweden. Uppsala, University of Exeter.

Coles, J. M. 2005. Shadows of Northern Past. Rock Carvings in Bohuslän and Østfold. Oxford, Oxbow Books. 
Coles, J. M. 2019. Yesterday's Man. An archaeological life 1955-1980. Crediton. WARP.

Coles, J., Bewley, R. H. and Mellars, P. A. (eds). 1999. World Prehistory. Studies in memory of Grahame Clark. Proceedings of the British Academy 99.

Coles, J. M. and Coles, B. J. 1989. Prehistory of the Somerset Levels. Hertford, Somerset Levels Project.

Coles, J. and B. 1996. Enlarging the Past. The Contribution of Wetland Archaeology. The Rhind Lectures for I994-5. Edinburgh, Society of Antiquaries of Scotland Monograph Series II and WARP Occasional Paper Io.

Coles, J. M. and Harding, A. F. 1979. The Bronze Age in Europe. An Introduction to the Prehistory of Europe c. 2000-700 BC. London, Methuen.

Coles, J. and Higgs, E. S. 1969. The Archaeology of Early Man. London, Faber and Faber.

Coles, J. and Higgs, E. S. 1975. The Archaeology of Early Man. Second Edition. Harmondsworth, Penguin Books.

Coles, J. M. and Lawson, A. J. (eds). 1987. European Wetlands in Prehistory. Oxford, Clarendon Press.

Coles, J. M. and Orme, B. J. 1980. Prehistory of the Somerset Levels. Hertford. Somerset Levels Project.

Coles, J. M. and Simpson, D. D. A (eds). 1968. Studies in Ancient Europe. Essays presented to Stuart Piggott. Leicester, Leicester University Press.

Marciniak, A. and Coles, J. (eds). 20Io. Grahame Clark and His Legacy. Newcastle upon Tyne, Cambridge Scholars Publishing.

\section{The other references cited}

Brzeziński, W. and Piotrowska, D. 20I2. A Portrait of Professor Zdzisław A. Rajewski (1907-1974). Scholar of Many Talents. Archaeologia Polona 50(2019): 27-62.

Clark, J. G. D. 1952. Prehistoric Europe: the Economic Basis. London, Methuen.

Clark, J. G. D. 1954. Excavations at Star Carr. An Early Mesolithic site at Seamer near Scarborough, Yorkshire. Cambridge, University Press.

Clark, J. G. D. 1957. Europa przedhistoryczna. Podstawy gospodarcze [Prehistoric Europe: the Economic Basis]. Translated by J. Kostrzewski. Warszawa, Państwowe Wydawnictwo Naukowe.

Clark, J. G. D. 1972. Star Carr: a case study in bioarchaeology. Reading, Massachusetts, Addison-Wesley. Module in Anthropology io.

Clark, G. 1989. Prehistory at Cambridge and beyond. Cambridge, Cambridge University Press.

Coles, B. (ed). 1992. The Wetland Revolution in Prehistory. Proceedings of a conference held by The Prehistoric Society and WARP at the University of Exeter April I9gr. Exeter, The Prehistoric Society and WARP. WARP Occasional Paper 6.

Coles, J. M. 196r. Scottish swan's-neck sunflower pins. Proceedings of the Antiquaries of Scotland 92 (I958-59): I-9.

Coles, J. M. 1963c. Archaeology by experiment. Illustrated London News 1963: 299-30I.

Coles, J. M. 1976. Forest Farmers: some archaeological, historical and experimental evidence relating to the prehistory of Europe. In S. J. de Laet (ed.), Acculturation and Continuity in Atlantic Europe, mainly during the Neolithic period and the Bronze Age. Papers presented at the Fourth Atlantic Colloquium, Ghent 1975, 59-66. Brugge, De Tempel. Dissertationes Archaeologicae Gandenses XVI.

Coles, J. 1977. Archeologia doświadczalna [Archaeology by Experiment]. Translated by Maria Miśkiewicz. Warszawa, Państwowe Wydawnictwo Naukowe. 
I76 Danuta Piotrowska and Wojciech Piotrowski

Coles, J. M. 1990b. Guidelines on waterlogged wood. The recording, sampling, conservation and curation of structural wood. In J. M. Coles, B. J. Coles and M. J. Dobson (eds), Waterlogged Wood. The recording, sampling, conservation and curation of structural wood: proceedings of a conference sponsored by WARP and English Heritage, 39-49. Exeter and London, WARP and English Heritage. WARP Occasional Paper 3.

Coles, J. M. 1991. From the waters of oblivion. Assen, Reuvens-Lezing 2. Stichting voor de Nederlandse Archeologie.

Coles, J. 1997b. Experimental Archaeology. In W. Brzeziński and W. Piotrowski (eds), Proceedings of the First International Symposium on Wood Tar and Pitch, 307-312. Warszawa, State Archaeological Museum in Warsaw.

Coles, J. 20or. The Wetland Archaeology Research Project. In B. Coles and A. Olivier (eds), Assistant Editor D. Bull. The Heritage Management of Wetlands in Europe, vii-viii. Exeter, Europae Archaeologiae Consilium Occasional Paper I WARP Occasional Paper 16.

Coles, J. 20ora. Of water-wings and wellingtons: wetland archaeology and the new journal. Journal of Wetland Archaeology i: 3-13.

Coles, J. 2oorb. Irish Wetland Archaeology: From Opprobrium to Opportunity. In B. Raftery and J. Hickey (eds), Recent Developments in Wetland Research, I-I2. Dublin, Seandálaíocht-Department of Archaeology, University College Dublin, Monograph Series 2, WARP Occasional Paper I4.

Coles, J. 2002. David and Goliath: the Fenland Survey. In T. Lane and J. Coles (eds), Essays in Honour of David Hall, I-9. Heckington, Sleaford, Lincolnshire Archaeology and Heritage Reports Series No 5, WARP Occasional Paper 17.

Coles, J. 2009. Review: Danuta Piotrowska, Prolegomena do archeologii Biskupina. Tom I. Bibliografia archeologiczna Biskupina 1933-1983 [Prolegomenon to the archaeology of Biskupin. Volume I. An archaeological bibliography of Biskupin 1933-1983]. Warszawa: Państwowe Muzeum Archeologiczne 2008, pp. 464, I3 figs. Archaeologia Polona 47: 289-291.

Coles, J. 20Io. Grahame Clark - a personal perspective. In A. Marciniak and J. Coles (eds), Grahame Clark and His Legacy, 3-26. Newcastle upon Tyne, Cambridge Scholars Publishing.

Coles, J. M., Coles, B. J. and Dobson, M. J. (eds). I990. Waterlogged Wood. The recording, sampling, conservation and curation of structural wood. Proceedings of a conference sponsored by WARP and English Heritage on IS January 199o. Exeter and London, WARP Occasional Paper 3.

Coles, J. M. and Hall, D. 1998. Changing Landscapes: The Ancient Fenland. Exeter, Cambridgeshire County Council and WARP. WARP Occasional Paper 13.

Coles, J. M. and Livens, R. G. 1960. A bronze sword from Douglas, Lanarkshire. Proceedings of the Antiquaries of Scotland 9I(1957-58): 182-186.

Fagan, B. 200I. Grahame Clark. An Intellectual Life of an Archaeologist. Boulder, Colorado and Oxford, Westview Press.

Harding, A. F. (ed.). 1999. Experiment and Design. Archaeological Studies in Honour of John Coles. Oxford, Oxbow Books.

Kostrzewski, J. 1970. Z mego życia. Pamiętnik [From my life. Memoirs]. Wrocław, Zakład Narodowy im. Ossolińskich - Wydawnictwo.

Lech, J. 20I0. Grahame Clark and archaeology in Poland: 1932-2007. In A. Marciniak and J. Coles (eds), Grahame Clark and His Legacy, I60-187. Newcastle upon Tyne, Cambridge Scholars Publishing. 
Minnitt, S. and Coles, J. 1996. The Lake Villages of Somerset. Glastonbury, Glastonbury Antiquarian Society, Somerset Levels Project and Somerset County Council Museums Service.

O’Sullivan, A. 2020. John Morton Coles (1930-2020). Archaeology Ireland. Winter 2020: 9.

Piotrowska, D. 1997-1998. Biskupin 1933-1996: archaeology, politics and nationalism. Archaeologia Polona 35-36: $255-285$.

Piotrowska, D. 2004. The State Archaeological Museum in Warsaw during World War II. Archaeologia Polona 42: 255-290.

Piotrowska, D. and Piotrowski, W. 2009. The International Symposium: The history of archaeology and archaeological thought in the 2oth century, dedicated to Professor Grahame Clark on the centenary of his birth, and on the 5oth anniversary of the Polish edition of G. Clark's Prehistoric Europe: the economic basis, Biskupin, 23rd-25th May 2007. Archaeologia Polona 47(20II): 243-26I.

Piotrowski, W. 1985. Wystawa „Biskupin Poland's Iron Age Lake Village” w Cambridge w Wielkiej Brytanii [Exhibition "Biskupin Poland's Iron Age Lake Village" in Cambridge in Great Britain]. Biuletyn Informacyjny Zarządu Muzeów i Ochrony Zabytków 156: 70-7I.

Piotrowski, W. 1990. Biskupin: fortified settlement of the Lusatian culture. In J. M. Coles, B. J. Coles and M. J. Dobson (eds), Waterlogged Wood. The recording, sampling, conservation and curation of structural wood. Proceedings of a conference sponsored by WARP and English Heritage on Is January 1990, 37-38. Exeter and London, WARP Occasional Paper 3.

Piotrowski, W. 199I-I992. The Wetland Revolution in Prehistory - konferencja w Exeter 5-7 kwietnia I99I roku [The Wetland Revolution in Prehistory - a conference held at Exeter in I99I April 5-7]. Wiadomości Archeologiczne 52(2): 235-236.

Piotrowski, W. 1998. The importance of the Biskupin Wet Site for Twentieth-Century Polish Archaeology. In K. Bernick (ed.), Hidden Dimensions. The Cultural Significance of Wetland Archaeology, 89-Io6. Vancouver, UBC Press.

Powell, T. G. E. 1966. Prehistoric Art. London, Thames and Hudson.

Reinerth, H. 1928. Die Wasserburg Buchau. Eine befestigte Inselsiedlung aus der Zeit II00-800 v. Chr. Augsburg, Führer zur Urgeschichte 6.

Renfrew, C. and Bahn, P. 1991. Archaeology. Theories, Methods and Practice. London, Thames and Hudson.

Reynolds, P. J. 1979. Iron Age Farm. The Butser Experiment. London, Collonade Books/British Museum Publication.

Schöbel, G. 2006. Die „Wasserburg Buchau” - eine Ufersiedlung der Spätbronzezeit am Federsee. In W. Blajer (ed.), Aus den Forschungen über das Siedlungswesen der Bronze-und frühen Eisenzeit in Mitteleuropa, 205-218. Kraków, Wydawnictwo Uniwersytetu Jagiellońskiego.

Smith, P. J. 2009. A "Splendid Idiosyncrasy": Prehistory at Cambridge I9I5-50. Oxford, Archeopress. British Archaeological Reports British Series 485.

Trigger, B. G. 2007. A History of Archaeological Thought. Cambridge, Cambridge University Press. Second Edition. 